published on smallpox and measles: his texts continued to be reprinted well into the 19th century. The medical texts of Ibn Rushd (Averroes) were also widely used in European universities.

Ibn Sina (Avicenna) was known in the West as "the prince of physicians." His synthesis of Islamic medicine, al-Qanun fil tibb (The Canon of Medicine), was the final authority on medical matters in Europe for several centuries. Although Ibn Sina made advances in pharmacology and in clinical practice, his greatest contribution was probably in the philosophy of medicine. He created a system of medicine that today we would call holistic and in which physical and psychological factors, drugs, and diet were combined in treating patients.?

Eventually, the Islamic civilisation constructed by the Arabs went into decline. In the east, new powers rose: first the Mongols, who in 1258 devastated Bagh$\mathrm{dad}$, the greatest Arab city of its day, and later the Ottoman Turks, who brought large parts of the Arab world into their new empire from the 14th century onwards. Weakened by internal strife and civil conflict, most of the Islamic cities of Spain had been conquered by Christian armies by the 14th century. The last Islamic state in Spain, Granada, surrendered to the Spanish in 1492 and its ruler, Boabdil, was exiled to North Africa. ${ }^{8}$
The flow of technology and ideas from the Islamic world to the West slowed and, in the past 600 years, has reversed. Academics and politicians still debate the reasons for and consequences of this decline in Islamic science and technology. The legacy of Islamic civilisation, though, remains with us in making possible Europe's own scientific and cultural renaissance. ${ }^{9}$

\section{Azeem Majeed professor of primary care}

(a.majeed@imperial.ac.uk)

Department of Primary Care and Social Medicine, Imperial College Faculty of Medicine, London W6 8RP

Competing interests: None declared.

1 HRH Prince of Wales. Islam and the West: speech at Oxford Centre for Islamic Studies, 1993. www.princeofwales.gov.uk/speeches/religion 27101993.html (accessed 3 Dec 2005).

2 Drabu R, Nanji A, Greenfield S. Science and learning in Islam-a shared legacy. Royal Institution of Great Britian, London, 1 December 2005.

Soubani AO, Khan FA. The discovery of the pulmonary circulation revisited. www.kfshrc.edu.sa/annals/152/mh9422ar.html (accessed 3 Dec 2005).

4 Aschoff A, Kremer P, Hashemi B, Kunze S. The scientific history of hydrocephalus and its treatment Neurosurg Rev 1999;22:67-93.

5 Al-Hassani STS. Thousand years of missing history. Manchester: Foundation for Science, Technology and Civilisation, 2004.

6 Van Alphen J, Aris A. Oriental medicine: an illustrated guide to the Asian arts of healing. London: Serindia, 2003.

7 Wear A, Geyer-Kordesch J, French R. Doctors and ethics: the historical setting of professional ethics. Rodopi: Amsterdam, 1993.

Fletcher R. Moorish Spain. London: Phoenix, 2001.

9 Bulliet R. The case for Islamo-Christian civilization. Irvington, NY: Columbia University Press, 2004.

\title{
How Google is changing medicine
}

\author{
A medical portal is the logical next step
}

$\mathrm{W}$

hat a remarkable year it has been for those of us monitoring changes in the global information landscape. Since last Christmas, there has been a flurry of activity: the digitisation of the world's libraries began in earnest (despite the copyright fracas); open access publishing gained much-needed support internationally (especially in science and medicine); and Google, MSN Search, and Yahoo introduced a number of customisation tools for desktops and mobiles, podcasts, blogs, and video searches. ${ }^{12}$

Google's influence and power is writ large in the search field-so large that librarians are asking themselves some difficult questions. With all of this technology and freely available digital information, what will happen to physical libraries? Google's mission is to provide access to the world's information-but this is librarians' mission too. Will they be needed in the new information age? ${ }^{3}$

For all the benefits technology provides, it does provoke anxiety. In a recent letter in the New England Journal of Medicine, a New York rheumatologist describes a scene at rounds where a professor asked the presenting fellow to explain how he arrived at his diagnosis. ${ }^{4}$ Matter of factly, the reply came: "I entered the salient features into Google, and [the diagnosis] popped right up." The attending doctor was taken aback by the Google diagnosis. "Are we physicians no longer needed? Is an observer who can accurately select the findings to be entered in a Google search all we need for a diagnosis to appear-as if by magic?" education is headed is anyone's guess. ${ }^{5}$ Googling your diagnosis; Googling your treatment-where is all this leading us?

Google has won the battle of the search engines, at least for the time being (see example in table), and its more serious minded offspring, Google Scholar, is rapidly gaining ground. Within a year of its release Google Scholar has led more visitors to many biomedical journal websites than has PubMed (J Sack, personal communication, 2005). Once they discover it, many medical students and doctors prefer Google Scholar. ${ }^{6}$ Although both tools benefit from Google's trademark simplicity, Google Scholar indexes more peer reviewed research and is especially quick in locating highly cited items and the proverbial needle in a haystack. Doctors are encouraged to consult Google Scholar for browsing and serendipitous discovery, not for literature reviews; and they should use the advanced search page to find words and names that occur often in the medical literature.

Which search engines bring visitors to bmj.com (November 2005)

\begin{tabular}{lc} 
Source & Number \\
\hline Google & 345756 \\
\hline Google Scholar & 105185 \\
\hline Yahoo & 57967 \\
\hline PubMed (Medline) & 14522 \\
\hline PubMed Central & 9616 \\
\hline HighWire Portal & 8617 \\
\hline MSN & 2336
\end{tabular}


Scholar's mode of presentation hinders its usefulness and may take up valuable time. Google's algorithm-which weighs the significance of articlesmay be partly to blame. The quantity of search results is acceptable, but quality is often not. Using some of the subject tags in advanced mode may offer some assistance, and more precision. Because current articles are not displayed first, and cannot be sorted, downloaded, or emailed-expect to do a lot of sifting.

Still, Scholar does simplify basic searching for doctors, and it's free, like PubMed (www.pubmed.gov). For anyone not affiliated with a large medical centre or university, the ability to search for and access research material that is available free on the web is a boon.

As scientific societies and associations consider moving their journals to open access models, Google Scholar and Elsevier's Scirus (www.scirus.com/ srsapp/) will likely provide a reliable gateway to this information. The most useful feature to come out this year on Google Scholar is "cited by" referencing. This free tool links searchers to other scholarly papers that have cited the paper being viewed. Scholar also provides links to local library catalogues through its library link program and through an international database called WorldCat.

In searches for clinical trials and systematic reviews, Google Scholar should of course never be used in isolation. However, it is a useful addition to PubMed, Cochrane, and other trusted sources of information, such as the TRIP or UpToDate databases, or a good medical librarian. For hard to find government or conference papers, don't forget to search regular Google in addition to Google Scholar. ${ }^{8}$

Some basic questions remain for Google Scholar. What does Google consider "scholarly"? Will Google ever tell us exactly what is in the database? Could the Google algorithm present the most current research at the top of the results display? And how often will Google update the database? ${ }^{9} 10$

What do we make of Google's future? Google's past success seems predicated on a simple business principle: do no evil. Founders Sergey Brin and Larry Page are said to be interested in using Google's computers to advance the cause of medical science. Apparently, Google's data mining techniques are well suited to analysing gene sequences in the human genome project. It may even be possible for patients to "google their own genes" one day. ${ }^{11}$

But "do no evil" is a far cry from "do what's best for humanity." Google is still a business. However, if it wishes to do something for medicine, Google should consider creating a medical portal. Call it Google Medicine; design an interface with medical filters and better algorithms; lead to the best evidence (just don't forget to consult with librarians about where the evidence is located). This kind of all purpose tool is badly needed in medicine, particularly for developing countries.

Build Google Medicine. The benefits to human health would be immeasurable.

\section{Dean Giustini $U B C$ biomedical branch librarian}

(giustini@interchange.ubc.ca)

University of British Columbia, Vancouver, BC, Canada V6T 1Z1

Competing interests: None declared.

1 Price G. A look back as Google's Library project passes the one year mark. Search Engine Watch. 13 Dec 2005. http://blog. searchenginewatch.com/blog/051213-155047 (accessed 14 Dec 2005).

2 Dimov V. Text-to-speech programs and continuous medical education. Computers and Internet. Jan 2004. http://net7.blogspot.com/2004/01/ text-to-speech-programs-and-continuous.html (accessed $14 \mathrm{Dec} 2005$ ).

3 Lindberg DAB, Humphreys BL. 2015-the future of medical libraries. N Engl J Med 2005;352:1067-70. 4 Greenwald R. ...And a diagnostic test was performed. $N$ Engl J Med

5 Green ML, Ruff TR. Why do residents fail to answer their clinical questions? A qualitative study of barriers to practicing evidence-based medicine. Acad Med 2005;80:176-82

6 Dimov V. How doctors use Google. Clinical Cases and Images-Blog. 15 Jun 2005. http://casesblog.blogspot.com/2005/06/how-doctors-usegoogle.html (accessed 14 Dec 2005).

7 Giustini D, Barsky E. A look at Google Scholar, PubMed and Scirus. J Can Health Libraries Assoc 2005;26:85-9.

8 Giustini D. University of British Columbia Library. Searching for grey literature. http://tobylibrary.ubc.ca/subjects/subjpage2.cfm?id $=877$ (accessed 5 Dec 2005)

9 Jacso P. Peter's digital reference shelf: Google Scholar beta. Dec 2004. www.galegroup.com/servlet/HTMLFileServlet?imprint=9999\&.region= 7\&fileName $=/$ reference $/$ archive $/ 200412 /$ googlescholar.html (accessed 14 Dec 2005)

10 Henderson J. Google Scholar: a source for clinicians. CMAJ 2005;172:1549-50. www.cmaj.ca/cgi/content/full/172/12/1549 (accessed 14 Dec 2005).

11 Vise D. The Google story: an excerpt. Chapter 26: Google your genes. 14 November 2005. www.washingtonpost.com/wp-dyn/content/article/ 2005/11/11/AR2005111100674.html (accessed 14 Dec 2005).

\section{Choice}

\section{More can mean less}

$\mathrm{F}$ or the NHS, 2006 might well be the year of choice. The UK government's plans for "empowering patients to play a bigger role in choosing where and who provides them with their health service" are finally to become reality. ${ }^{12}$ These plans will be supported by the twin pillars of competition, and plurality of provision. To be pro-choice is clearly to be on the side of the angels, or at least the politicians. Spare a thought this Christmas, therefore, for a small group of people who insist there is another side to the argument.

In a recent bestselling business book, psychologist Barry Schwartz argues that the amount of choice on offer in life exceeds our ability to effectively exercise that choice, or even to enjoy it. ${ }^{3}$ The debilitating effects of choice overload may be bewilderment and high levels of anxiety and stress. When a brush with illness in the United States caused health economist Rhiannon Tudor Edwards to question the value of choice in health care, she concluded that having less choice in health care is a price well worth paying for universal coverage. ${ }^{4}$ The UK Public Administration Select Committee wisely advises caution, calling on the government to be more realistic about the role and limitations of choice. ${ }^{5}$ The paradox of choice is that more can sometimes mean less.

Support for the concept of choice is neither universal nor unconditional. The London Patient Choice BMJ 2005;331:1488-9 